\title{
Podocyte Biology and the Emerging Understanding of Podocyte Diseases
}

\author{
Laura Barisoni $^{a}$ Peter Mundel ${ }^{\mathrm{b}}$ \\ a Department of Pathology, The Johns Hopkins University, Baltimore, Md., and bivision of Nephrology, \\ Albert Einstein College of Medicine, Bronx, N.Y., USA
}

\section{Key Words}

Focal segmental glomerulosclerosis · Minimal-change disease $\cdot$ Slit diaphragm

\begin{abstract}
The understanding of the unique molecular apparatus of the podocyte has increased dramatically in recent years. This new knowledge has improved the diagnosis and classification of the diseases that have been termed podocytopathies. Podocyte injury frequently leads to reorganization of the slit diaphragm and reorganization of the foot process structure. Four major causes of foot process effacement can be identified, with some due to genetic mutations and others due to acquired conditions: (1) impaired formation of the slit diaphragm complex; (2) abnormalities of the glomerular basement membrane or the adhesion of podocytes to the glomerular basement membrane; (3) abnormalities of the actin cytoskeleton and associated proteins, and (4) alterations in the apical membrane domain of the podocyte. The major podocytopathies can also be organized into four categories, including those with a normal glomerular histology, diffuse mesangial sclerosis, focal segmental glomerulosclerosis, and collapsing glomerulopathy.
\end{abstract}

Copyright $@ 2003$ S. Karger AG, Basel

\section{Introduction}

Podocytes are highly differentiated cells with a complex cellular morphology. They are located inside the kidney glomerulus, a twisted globe of capillaries through which the blood is filtered hydrostatically through a highvolume/high-discrimination filter [1-3]. Podocyte foot processes are anchored to the glomerular basement membrane (GBM) via $\alpha_{3} \beta_{1}$-integrin [4] and $\alpha$ - and $\beta$-dystroglycans $[5,6]$. Neighboring foot processes are connected by a specialized cell-cell junction, the glomerular slit diaphragm, which represents the main size-selective filter barrier in the kidney [1-3]. The slit diaphragm is thought to be a modified adherens junction [7]. Our understanding of its molecular components continues to grow; the slit diaphragm is known to include P-cadherin [7], nephrin [8-10], the giant protocadherin mFATq $[11,12]$, podocin [13], and Neph1 [14-16].

Podocytes are injured in many forms of human and experimental glomerular disease, including minimalchange disease (MCD), focal segmental glomerulosclerosis (FSGS), collapsing glomerulopathy, diabetic nephropathy, membranous glomerulopathy, crescentic glomerulonephritis, and lupus nephritis [1, 3, 17]. Independent of the underlying disease, the early events are characterized by molecular alterations of the slit diaphragm without visible morphological changes or, more obviously, by a reorganization of the foot process structure with fusion of filtration slits and apical displacement of the slit diaphragm

\footnotetext{
Laura Barisoni, MD

Department of Pathology, Renal Pathology Laboratory

NYU, Tisch Hospital, Room TH 480

560 First Avenue, New York, NY 10016 (USA)

Tel. +1 212263 5472, Fax +1 212263 0783,E-Mail laura.barisoni@med.nyu.edu
} 
Fig. 1. Simplified schematic showing the molecular anatomy of the podocyte foot processes [modified from ref. 83]. The four boxes 1-4 in the right half define the four domains of the foot processes: SD complex (1), basal domain and GBM (2), actin cytoskeleton (3), and apical plasma domain with glycocalyx. Of note, interference with any of these four domains can cause foot process effacement and nephrotic syndrome.

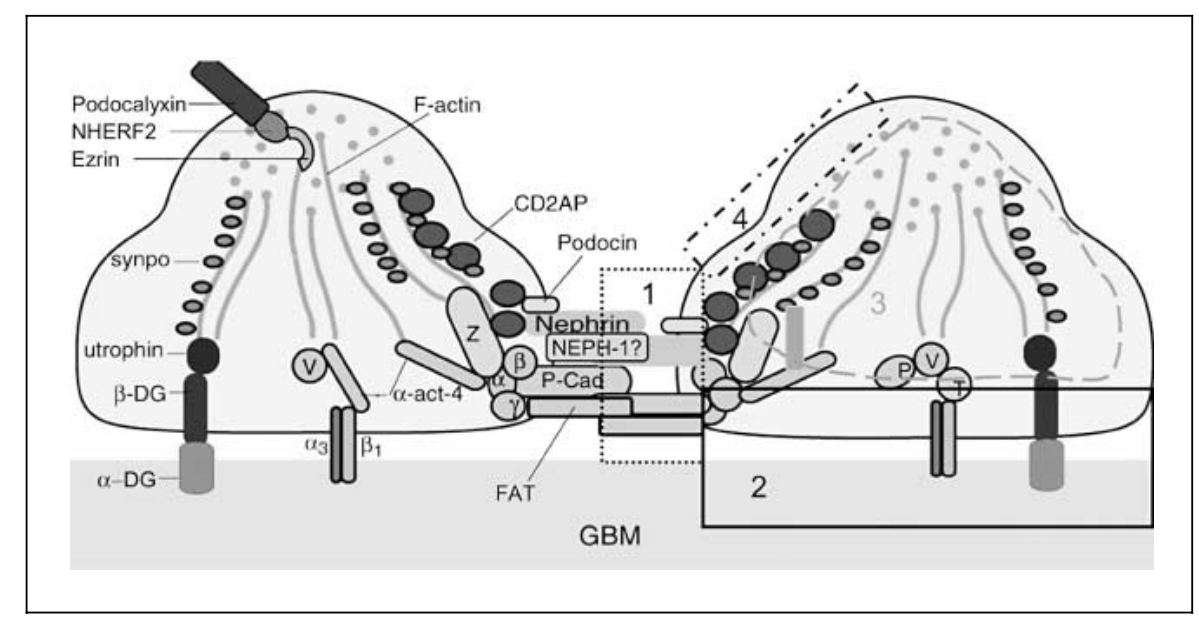

$[1,18,19]$. Based on recent progress in the molecular pathology of podocytes, four causes of foot process effacement and proteinuria can be identified (fig. 1): (1) impaired formation of the slit diaphragm complex and its associated lipid rafts; (2) abnormalities in the GBM or the adhesive interaction between the podocyte and the GBM [5, 6, 20-25]; (3) abnormalities of the actin cytoskeleton $[26,27]$, and (4) alterations in the apical membrane domain of podocytes [28-31].

\section{Slit Diaphragm in Normal and Diseased Glomeruli}

The slit diaphragm is a complex of proteins located in the extracelluar space, bridging adjacent foot processes and measuring $30-40 \mathrm{~nm}$ in length [1-3]. The recent discovery of several novel podocyte proteins and their mutation analysis, including mFAt1 [12], the nephrin homologue Neph1 [14], nephrin [32], CD2-associated protein (CD2AP) [33, 34], and podocin [35], have emphasized the critical role of the slit diaphragm in maintaining the normal function of the glomerular filtration barrier. However, the mechanisms regulating the structural changes that occur during foot process fusion are still largely unknown. A fuller understanding of the molecular basis of glomerular kidney disease requires elucidation of the relationship between slit diaphragm proteins and the maintenance of foot process structure. A simplified schematic of the foot processes and the molecular makeup of the slit diaphragm complex is shown in figure 1.

The identification of the nephrin gene NPHSI by positional cloning elucidated the genetic defect underlying the congenital nephrotic syndrome of Finnish type. Nephrin is a large transmembrane molecule with immunoglobulinlike domains. The role of nephrin in the pathogenesis of foot process effacement has been also confirmed by injection of antinephrin antibody in animals which resulted in foot process effacement [36]. Similarly, inactivation of NPHS1 in mice resulted in proteinuria and partial effacement of the foot processes [37, 38]. In a rat model of antibody-induced foot process effacement, it has been shown that nephrin oligomers associate within signaling microdomains of the plasma membrane, also known as lipid rafts, and that these localize to the slit diaphragm [39]. The in vivo injection of an antibody against a podocytespecific ganglioside leads to morphological changes of the filtration slits resembling foot process effacement [40]. In this model of foot process effacement, nephrin dislocates to the apical pole of the narrowed filtration slits and undergoes tyrosine phosphorylation [39]. These data suggest that lipid rafts are important in the spatial organization of the slit diaphragm under both physiological and pathological conditions [39] and that tyrosine phosphorylation of slit diaphragm proteins may regulate their subcellular redistribution. Redistribution of nephrin on the luminal side of podocytes has also been described in human nephrotic syndrome [41].

NPHS2 is the genetic cause of autosomal recessive, steroid-resistant nephrotic syndrome in some patients [35, 42, 43] and may also cause sporadic FSGS [44]. The NPHS2 gene product, podocin, is a new member of the stomatin family of hairpin-like integral membrane proteins with intracellular $\mathrm{N}$ and $\mathrm{C}$ termini. Stomatin is present as high-order oligomer in erythrocyte lipid rafts, where it may serve a scaffolding function [45]. Podocin 
localizes to the podocyte foot process membrane, at the insertion site of the slit diaphragm [13]. Like nephrin, podocin oligomers form in lipid raft. Moreover, glutathione S-transferase pull down experiments revealed that podocin associates via its $\mathrm{C}$ terminus with CD2AP and nephrin. Co-immunoprecipitation of proteins from glomerular extracts demonstrates that podocin interacts with CD2AP and nephrin. Furthermore, in vitro studies revealed a direct interaction of podocin and CD2AP [13]. Hence, similar to the role of stomatin in erythrocytes, podocin may act as a scaffolding protein, serving in the structural organization of the slit diaphragm and the regulation of its filtration function $[12,20]$.

mFAT1 is a nonclassical giant protocadherin which was previously localized to the slit diaphragm [11]. Mice lacking mFAT1 exhibit perinatal lethality, most probably caused by loss of the renal glomerular slit junctions and fusion of podocyte foot processes [12]. These data confirm a necessary role for FAT 1 in the development of the slit diaphragm, a modified adhesion junction of podocytes [12].

Although podocytes lack the junctional complexes typical of polarized epithelial cells, the podocyte slit diaphragms have been reported to share some proteins with tight junctions, such as zona occludens ( $\mathrm{ZO}) 1$. ZO-1 is located on foot process at the point of insertion of slit diaphragms [46]. ZO-1 interacts with the actin-based cytoskeleton and may also participate in signaling events through tyrosine phosphorylation [47]. ZO-1 may have an important role in regulating the function of the slit diaphragm [7]. In support of a functional role for ZO-1, spontaneously proteinuric Munich Wistar Frömter rats have normal podocyte foot processes and slit diaphgrams, with the only apparent defect presenting as a redistribution of ZO-1 in the cytoplasm and on the cytoplasmic surface of the cell membrane [48].

\section{Podocyte Adhesion to the GBM}

The glomerular filtration barrier is composed of fenestrated endothelium, GBM, and the podocyte foot processes and slit diaphragms. An intact glomerular filtration barrier is a critical element of the normal kidney function, and failure of this filtration complex leads to proteinuria. Proteinuria is invariably associated with foot process effacement, flattening, and retraction. To maintain the highly ordered foot process architecture, the adhesion of the podocyte to the underlying GBM is tightly controlled by the expression of particular proteins. $\alpha_{3} \beta_{1}$-integrin binds to several components of the GBM such as collagen IV, fibronectin, laminin, and endactin/ nidogen. Ligand binding induces clustering of integrins to form focal adhesions and recruitment of intracellular cytoskeletal proteins [49]. These findings suggest that the integrin-binding status in podocytes might influence the cytoskeletal organization and thereby contribute to determining the foot process shape [49]. Blockade of the $\beta_{1^{-}}$ integrin-binding domain by specific antibodies leads to foot process effacement, proteinuria, and detachment of the podocytes from the GBM [4, 50-52]. In addition, podocytes can express $\beta_{4}$-integrin which may affect the glomerular permeability in FSGS [53].

Dystroglycans are heterodimeric proteins composed of a transmembrane component, the beta subunit, and an extracellular component, the alpha subunit. Dystroglycans are connected to the actin-based cytoskeleton through dystrophin (in skeletal muscle) and urotrophin (in the podocyte). Both integrins and dystroglycans are coupled to the podocyte actin cytoskeleton. Interestingly, the dystroglycan expression is lost only in $\operatorname{MCD}[5,6]$. Moreover, in MCD, the dystroglycan expression is negatively correlated with disease activity: when proteinuria occurs, the dystroglycan expression is markedly reduced, and foot processes are effaced, but, once the foot processes are restored, dystroglycan expression returns to normal. This phenomenon appears to be specific for MCD. In FSGS, the expression of dystroglycans remains unchanged, suggesting that other mechanisms must be responsible for podocyte detachment.

Podocyte detachment from the GBM, whether from apoptosis, necrosis, or loss of adhesive interaction, may play a central role in the pathogenesis of FSGS, particularly in hyperfiltration FSGS, as proposed by Kriz et al. [54]. Podocytes undergo morphological changes, including foot process effacement, reorganization of the cytoskeleton, pseudocyst formation within the podocyte cytoplasm, and detachment from the GBM, leaving the GBM denuded [54-56]. Podocytes lack proliferative capacity under normal circumstances and cannot repopulate denuded areas. Instead, parietal epithelial cells contact the denuded GBM to form a synechia and ultimately a scar.

\section{Foot Process Cytoskeleton}

Foot processes contain an elaborate and dynamic actin-based cytoskeleton. This structure maintains the normal architecture of the foot processes, including the proper positioning of transmembrane proteins and the slit dia- 
phragm. The major molecular components of the cytoskeleton are actin, $\alpha$-actinin [57, 58], and synaptopodin $[59,60]$. In nephrotic syndromes, the actin-based cytoskeleton is reorganized and is condensed against the sole of the podocyte foot process. Of note, the reorganization of the actin cytoskeleton is preceded by upregulation of $\alpha$-actinin [26]. $\alpha$-Actinin-4 is an actin filament cross-linker, shown to be involved in certain forms of FSGS [27, 61]. Also, it has been shown that, among the spectrum of diseases with nephrotic syndrome and podocyte injury, the synaptopodin expression correlates with the severity of the disease and is well preserved in benign forms of nephrotic syndrome, such as MCD, and reduced in less benign forms such as FSGS [62-64]. Several recent studies reveal a direct interaction between podocin, nephrin, and CD2AP; moreover, CD2AP interacts with actin, indicating a close relationship between the cytoskeletal structure and the configuration of the slit diaphragm [6567].

\section{Negative Surface Charge on the Luminal Cell Membrane}

The podocyte surface is divided into two parts by the slit diaphragm: the luminal side, facing the urinary space, and the abluminal side which corresponds to the sole of the foot processes and is located against the GBM. On the luminal side, podocytes are equipped with a well-developed glycocalyx, containing heavily sialylated glycoconjugates and sulfated molecules. This surface coat contributes to the negative charge of the filtration barrier and is mostly made of podocalyxin [68]. Podocalyxin is synthesized by glomerular endothelial cells and by podocytes and is inserted in the luminal side of the membrane during development, when foot processes and slit diaphragms are formed [69]. Podocalyxin is of critical importance for the formation and preservation of the characteristic cellular architecture of podocytes $[28,29,70]$ and possibly for preventing parietal cell adherence to podocytes. Podocalyxin knockout mice have immature glomeruli with flattened podocytes, supporting the theory that podocalyxin contributes directly to the stability of foot processes [31]. Another important molecule on the luminal membrane is GLEPP-1, a transmembrane protein tyrosine phosphatase with possible receptor function [71]. Its precise function in podocytes is not yet clear, but it has been proposed that GLEPP-1 plays a role in regulating the glomerular pressure/filtration rate relationship through an effect on podocyte structure and function [72].
The expression of podocalyxin and GLEPP-1 has been studied in nephrotic syndrome. Whereas in MCD, the expression of these molecules is well preserved, in FSGS and collapsing glomerulopathy, the expression of GLEPP1 and podocalyxin is reduced [62].

\section{Podocyte Transcription Factors}

The Wilms' tumor (WT) 1 expression is highly characteristic of podocytes, at any developmental stage. In the fetal kidney, WT1 is expressed in metanephric blastema, condensing mesenchyme, renal vesicles, and developing podocytes. In adult life, the WT1 expression is restricted to podocytes [73]. The $P A X 2$ gene encodes a transcription factor expressed early during development and is a WT1 target gene. The $P A X 2$ expression is downregulated when the WT1 expression increases in maturing glomeruli. Both WT1 and $P A X 2$ knockout mice lack kidneys, testifying to the critical importance of these transcription factors in metanephric development. Overexpression of $P A X 2$ generates multiple kidney abnormalities [74].

The WT1 expression is altered in certain congenital and acquired human diseases. In particular, the WT1 expression is lost in podocytes of both collapsed glomeruli and normal-appearing glomeruli in collapsing glomerulopathy, indicating that the podocyte phenotype is dysregulated [62]. The Denys-Drash syndrome is a rare disorder of urogenital development, characterized by the association of early-onset nephrotic syndrome, male pseudohermaphroditism, and nephroblastoma. Patients develop renal insufficiency by the age of 5 years. The glomerular lesions are characterized by diffuse mesangial sclerosis. Interestingly, in these patients, the WT1 expression is abnormal and is associated with increased expression of $P A X 2$. These findings are also associated with podocyte hyperplasia and expression of proliferating cell nuclear antigen, indicating that the podocytes have reentered the cell cycle [75]. The podocyte proliferation is also characteristic of collapsing glomerulopathy [76, 77].

Podl is a basic-helix-loop-helix transcription factor that is highly expressed in the mesenchyme of developing organs that include heart, lung, gut, and podocytes [78]. Mice lacking Pod 1 fail to develop mature glomeruli, and the podocyte development appears to be arrested at the S-shaped body stage [79].

Mutations in the LIM homeodomain transcription factor $L M X 1 B$ cause nail-patella syndrome, an autosomal dominant disease with skeletal abnormalities, nail hypoplasia, and nephropathy [24]. $L M X 1 B-/-$ podocytes have 
reduced numbers of foot processes, are dysplastic, and lack typical slit diaphragms, indicating an arrest in development, but they express near-normal levels of nephrin, synaptopodin, ZO-1, $\alpha_{3}$-integrin, and GBM laminins [38, $80,81]$. Several $L M X 1 B$-binding sites in the putative regulatory regions of both the genes encoding for CD2AP and podocin have been identified. Moreover, in vitro experiments demonstrated that $L M X 1 B$ binds to these sequences and can activate transcription through them in cotransfection assays. Thus, $L M X 1 B$ regulates the expression of multiple podocyte genes critical for podocyte differentiation and function. These data indicate that reduced levels of specific podocyte proteins may contribute to nail-patella syndrome associated nephropathy $[38,80$, 81].

Most recently it was shown that the mouse kreisler (Krml1/MafB) segmentation gene is required for differentiation of podocytes [82]. In contrast to $L M X B 1$ and Pod1, kreisler appears to be involved in the terminal steps of podocyte differentiation, including the formation of the normal elaborate foot process architecture [82]. Based on these findings, it will be very interesting to determine whether reduced kreisler expression leads to foot process effacement.

\section{Podocyte Response to Injury}

Podocyte injury, if not repaired, leads to severe progressive glomerular disease $[1,83]$. Early podocyte manifestations of injury include vacuolization, pseudocyst formation, and detachment from the GBM, resulting in podocyte depletion. These events underlie the formation of synechiae via attachment of parietal epithelial cells of Bowman's capsule to denuded GBM areas [54, 84]. These changes are irreversible and ultimately lead to the development of glomerulosclerosis and end-stage renal failure [54, 85]. Studies in human diabetic nephropathy [86-88], the chronic puromycin model of glomerulosclerosis [89], and transforming growth factor beta 1 (TGF- $\beta 1$ ) transgenic mice [90] collectively provided convincing evidence for a correlation between the loss of podocytes and the progression of glomerular diseases. For a comprehensive review see the recent paper by Böttinger and Bitzer [91].

The TGF- $\beta$ pathway controls an array of cellular responses to various forms of chronic glomerular injury, including extracellular matrix accumulation, proliferation, hypertrophy, and podocyte apoptosis [90, 92-96]. Increased expression of TGF- $\beta$ isoforms and components of the intracellular signaling system has been described in most animal models of glomerular disease and in progressive human disease, irrespective of the underlying etiology [97]. Together, these studies implicate the TGF- $\beta$ pathway as a key molecular signaling cascade involved in mediating cellular pathomechanisms resulting in glomerulosclerosis and interstitial fibrosis [95]. As described below, primary and secondary forms of FSGS are characterized by depletion of podocytes and constitute a central manifestation of chronic progressive glomerular diseases [98]. Podocytes undergo apoptosis at early stages during the course of progressive glomerulosclerosis in TGF- $\beta 1$ transgenic mice [90]. Apoptosis is associated with progressive depletion of podocytes and precedes mesangial expansion. Smad7 protein expression was strongly induced specifically in damaged podocytes of transgenic mice and in cultured murine podocytes treated with TGF- $\beta$. TGF- $\beta 1$ and Smad7 each induced apoptosis in podocytes, and their coexpression had an additive effect [90]. Activation of p38 mitogen-activated protein kinase and caspase 3 was required for TGF- $\beta$-mediated apoptosis, but not for apoptosis induced by Smad7. Unlike TGF- $\beta$, Smad7 inhibited nuclear translocation and transcriptional activity of the cell survival factor nuclear factor kappa B [90]. These results suggest a novel functional role for Smad7 as amplifier of TGF- $\beta$-induced apoptosis in podocytes and a new pathomechanism for podocyte depletion in progressive glomerulosclerosis [90].

\section{Classification of Podocytopathies}

Podocytes are injured in many forms of human and experimental glomerular diseases, including MCD, FSGS, collapsing glomerulopathy, membranous nephropathy, and diabetic nephropathy. Podocyte damage plays a central role in the pathomechanism of nephrotic syndrome. It has been demonstrated that numerous distinct molecular events, occurring in podocyte cell body, primary processes, nucleus, foot processes, and, in particular, in the slit diaphragm, can lead to foot process effacement and proteinuria. In line with these new discoveries in podocyte biology, we propose a new classification of podocyte diseases (table 1).

First are podocyte diseases with a normal glomerular histology. In MCD, a defect in the expression of dystroglycans seems to be the underlying molecular defect. In this case, nephrotic syndrome and podocyte damage are reversible. A more severe form of nephrotic syndrome is the congenital nephrotic syndrome of the Finnish type which rapidly progresses to renal failure. Recurrent FSGS fol- 
Table 1. Classification of podocyte diseases

\begin{tabular}{lll}
\hline Histology & Pathologic variant & Critical pathogenic factors \\
\hline Normal & $\begin{array}{l}\text { minimal-change disease } \\
\text { congenital nephrotic syndrome }\end{array}$ & $\begin{array}{l}\text { dystroglycan } \\
\text { nephrin }\end{array}$ \\
\hline Diffuse mesangial sclerosis & $\begin{array}{l}\text { Denys-Drash syndrome } \\
\text { Frasier syndrome }\end{array}$ & $\begin{array}{l}\text { WT1 } \\
\text { WT1 }\end{array}$ \\
\hline Focal segmental glomerulosclerosis & idiopathic & unknown \\
& genetic & podocin, $\alpha$-actinin-4, $\beta_{1}$-integrin, \\
& CD2AP, $L M X 1 B$ \\
& hyperfiltration & mechanical stress \\
\hline Collapsing glomerulopathy & idiopathic & unknown \\
& viral & HIV-1, Parvovirus B19, SV40? \\
\hline
\end{tabular}

lowing renal transplantation presents initially with a normal renal histology, later evolving into glomerulosclerosis, and has been associated with a plasma protein factor. Second are the syndromes with diffuse mesangial sclerosis, including Denys-Drash and Frasier syndromes, where the defect is WT1 mutation [99]. The third group of podocyte diseases is represented by FSGS. The damage can be idiopathic, related to molecular defects at the level of the slit diaphragm [35, 42], transcriptional factors, or actin cytoskeleton, or secondary to mechanical stress such as that driven by glomerular hyperfiltration [54-56]. The fourth category of podocyte diseases includes those characterized by collapse of the capillary loop. These include idiopathic collapsing glomerulopathy and HIV-1-associated collapsing glomerulopathy and are characterized by dedifferentiation, reflected by loss of maturity markers, dysregulation, reflected by loss of WT1 expression [62, 100], and de novo expression of other cell line characteristic markers, such as macrophage-specific proteins [44].

\section{References}

1 Somlo S, Mundel P: Getting a foothold in nephrotic syndrome. Nat Genet 2000;24:333335.

2 Tryggvason K, Wartiovaara J: Molecular basis of glomerular permselectivity. Curr Opin Nephrol Hypertens 2001;10:543-549.

3 Endlich K, Kriz W, Witzgall R: Update in podocyte biology. Curr Opin Nephrol Hypertens 2001;10:331-340.

4 Adler S: Characterization of glomerular epithelial cell matrix receptors. Am J Pathol 1992; 141:571-578.

5 Regele HM, Fillipovic E, Langer B, Poczewki H, Kraxberger I, Bittner RE, Kerjaschki D: Glomerular expression of dystroglycans is reduced in minimal change nephrosis but not in focal segmental glomerulosclerosis. J Am Soc Nephrol 2000;11:403-412.

6 Raats CJ, van den Born J, Bakker MA, OppersWalgreen B, Pisa BJ, Dijkman HB, Assmann KJ, Berden JH: Expression of agrin, dystroglycan, and utrophin in normal renal tissue and in experimental glomerulopathies. Am J Pathol 2000;156:1749-1765.

7 Reiser J, Kriz W, Kretzler M, Mundel P: The glomerular slit diaphragm is a modified adherens junction. J Am Soc Nephrol 2000;11:1-8.
8 Ruotsalainen V, Ljungberg P, Wartiovaara J, Lenkkeri U, Kestil M, Jalanko H, Holmberg C, Tryggvason K: Nephrin is specifically located at the slit diaphragm of glomerular podocytes. Proc Natl Acad Sci USA 1999;96:7962-7967.

9 Holthofer H, Ahola H, Solin ML, Wang S, Palmen T, Luimula P, Miettinen A, Kerjaschki D: Nephrin localizes at the podocyte filtration slit area and is characteristically spliced in the human kidney. Am J Pathol 1999;155:16811687.

10 Holzman LB, John PL, Kovari IA, Verma R, Holthofer H, Abrahamson DR: Nephrin localizes to the slit pore of the glomerular epithelial cell. Kidney Int 1999;56:1481-1491.

11 Inoue T, Yaoita E, Kurihara H, Shimizu F, Sakai T, Kobayashi T, Ohshiro K, Kawachi H, Okada H, Suzuki H, Kihara I, Yamamoto T: FAT is a component of glomerular slit diaphragms. Kidney Int 2001;59:1003-1012.

12 Ciani L, Patel A, Allen ND, Ffrench-Constant $\mathrm{C}$ : Mice lacking the giant protocadherin mFAT1 exhibit renal slit junction abnormalities and a partially penetrant cyclopia and anophthalmia phenotype. Mol Cell Biol 2003; 23:3575-3582.
13 Schwarz K, Simons M, Reiser J, Saleem MA, Faul C, Kriz W, Shaw AS, Holzman LB, Mundel P: Podocin, a raft-associated component of the glomerular slit diaphragm, interacts with CD2AP and nephrin. J Clin Invest 2001;108: 1621-1629.

14 Donoviel DB, Freed DD, Vogel H, Potter DG, Hawkins E, Barrish JP, Mathur BN, Turner CA, Geske R, Montgomery CA, Starbuck M, Brandt M, Gupta A, Ramirez-Solis R, Zambrowicz BP, Powell DR: Proteinuria and perinatal lethality in mice lacking neph 1 , a novel protein with homology to nephrin. Mol Cell Biol 2001; 21:4829-4836.

15 Gerke P, Huber TB, Sellin L, Benzing T, Walz $\mathrm{G}$ : Homodimerization and heterodimerization of the glomerular podocyte proteins nephrin and NEPH1. J Am Soc Nephrol 2003;14:918926.

16 Barletta GM, Kovari IA, Verma RK, Kerjaschki D, Holzman LB: Nephrin and Neph1 colocalize at the podocyte foot process intercellular junction and form cis hetero-oligomers. J Biol Chem 2003;278:19266-19271.

17 Eddy AA, Schnaper HW: The nephrotic syndrome: From the simple to the complex. Semin Nephrol 1998;18:304-316. 
18 Smoyer WE, Mundel P: Regulation of podocyte structure during the development of nephrotic syndrome. J Mol Med 1998;76:172183.

19 Reiser J, Von Gersdorff G, Simons M, Schwarz K, Faul C, Giardino L, Heider T, Loos M, Mundel P: Novel concepts in understanding and management of glomerular proteinuria. Nephrol Dial Transplant 2002;17:951-955.

20 Kreidberg JA, Donovan MJ, Goldstein SL, Rennke H, Shepherd K, Jones RC, Jaenisch R Alpha 3 beta 1 integrin has a crucial role in kidney and lung organogenesis. Development 1996;122:3537-3547.

21 Noakes PG, Miner JH, Gautam M, Cunningham JM, Sanes JR, Merlie JP: The renal glomerulus of mice lacking s-laminin/laminin beta 2:Nephrosis despite molecular compensation by laminin beta 1 . Nat Genet 1995;10:400406.

22 Miner JH, Sanes JR: Molecular and functional defects in kidneys of mice lacking collagen alpha 3(IV): Implications for Alport syndrome. J Cell Biol 1996;135:1403-1413.

23 Kretzler M, Teixeira VP, Unschuld PG, Cohen CD, Wanke R, Edenhofer I, Mundel P, Schlöndorff D, Holthofer H: Integrin-linked kinase as a candidate downstream effector in proteinuria. FASEB J 2001;15:1843-1845.

24 Morello R, Lee B: Insight into podocyte differentiation from the study of human genetic disease: Nail-patella syndrome and transcriptional regulation in podocytes. Pediatr Res 2002;51:551-558.

25 Morello R, Zhou G, Dreyer SD, Harvey SJ, Ninomiya Y, Thorner PS, Miner JH, Cole W, Winterpacht A, Zabel B, Oberg KC, Lee B: Regulation of glomerular basement membrane collagen expression by LMX1B contributes to renal disease in nail patella syndrome. Nat Genet 2001;27:205-208

26 Smoyer WE, Mundel P, Gupta A, Welsh MJ: Podocyte alpha-actinin induction precedes foot process effacement in experimental nephrotic syndrome. Am J Physiol 1997;273:F150 F157.

27 Kaplan JM, Kim SH, North KN, Rennke H, Correia LA, Tong HQ, Mathis BJ, RodriguezPerez JC, Allen PG, Beggs AH, Pollak MR Mutations in ACTN4, encoding alpha-actinin4 , cause familial focal segmental glomerulosclerosis. Nat Genet 2000;24:251-256

28 Orlando RA, Takeda T, Zak B, Schmieder S, Benoit VM, McQuistan T, Furthmayr H, Farquhar MG: The glomerular epithelial cell antiadhesin podocalyxin associates with the actin cytoskeleton through interactions with ezrin. J Am Soc Nephrol 2001;12:1589-1598.

29 Takeda T, McQuistan T, Orlando RA, Farquhar MG: Loss of glomerular foot processes is associated with uncoupling of podocalyxin from the actin cytoskeleton. J Clin Invest 2001; 108:289-301.

30 Seiler MW, Venkatachalam MA, Cotran RS Glomerular epithelium: Structural alterations induced by polycations. Science 1975;189: 390-393.
31 Doyonnas R, Kershaw DB, Duhme C, Merkens H, Chelliah S, Graf T, McNagny KM: Anuria, omphalocele, and perinatal lethality in mice lacking the CD34-related protein podocalyxin. J Exp Med 2001;194:13-27.

32 Kestila M, Lenkkeri U, Mannikko M, Lamerdin J, McCready P, Putaala H, Ruotsalainen V, Morita T, Nissinen M, Herva R, Kashtan CE, Peltonen L, Holmberg C, Olsen A, Tryggvason $\mathrm{K}$ : Positionally cloned gene for a novel glomerular protein - nephrin - is mutated in congenital nephrotic syndrome. Mol Cell 1998;1:575582.

33 Shih NY, Li J, Karpitskii V, Nguyen A, Dustin ML, Kanagawa O, Miner JH, Shaw AS: Congenital nephrotic syndrome in mice lacking CD2-associated protein. Science 1999;286: 312-315

34 Shaw AS, Miner JH: CD2-associated protein and the kidney. Curr Opin Nephrol Hypertens 2001;10:19-22.

35 Boute N, Gribouval O, Roselli S, Benessy F, Lee H, Fuchshuber A, Dahan K, Gubler MC, Niaudet P, Antignac C: NPHS2, encoding the glomerular protein podocin, is mutated in autosomal recessive steroid-resistant nephrotic syndrome. Nat Genet 2000;24:349-354.

36 Orikasa M, Matsui K, Oite T, Shimizu F: Massive proteinuria induced in rats by a single intravenous injection of a monoclonal antibody. J Immunol 1988;141:807-814.

37 Putaala H, Soininen R, Kilpelainen P, Wartiovaara $\mathrm{J}$, Tryggvason $\mathrm{K}$ : The murine nephrin gene is specifically expressed in kidney, brain and pancreas: Inactivation of the gene leads to massive proteinuria and neonatal death. Hum Mol Genet 2001;10:1-8.

38 Hamano Y, Grunkemeyer JA, Sudhakar A, Zeisberg M, Cosgrove D, Morello R, Lee B, Sugimoto H, Kalluri R: Determinants of vascular permeability in the kidney glomerulus. $\mathbf{J}$ Biol Chem 2002;277:31154-31162.

39 Simons M, Schwarz K, Kriz W, Miettinen A, Reiser J, Mundel P, Holthofer H: Involvement of lipid rafts in nephrin phosphorylation and organization of the glomerular slit diaphragm. Am J Pathol 2001;159:1069-1077.

40 Miettinen A, Dekan G, Farquhar MG: Monoclonal antibodies against membrane proteins of the rat glomerulus: Immunochemical specificity and immunofluorescence distribution of the antigens. Am J Pathol 1990;137:929-944.

41 Wernerson A, Duner F, Pettersson E, Widholm SM, Berg U, Ruotsalainen V, Tryggvason K, Hultenby K, Soderberg M: Altered ultrastructural distribution of nephrin in minimal change nephrotic syndrome. Nephrol Dial Transplant 2003;18:70-76.

42 Tsukaguchi H, Sudhakar A, Le TC, Nguyen T, Yao J, Schwimmer JA, Schachter AD, Poch E, Abreu PF, Appel GB, Pereira AB, Kalluri R, Pollak MR: NPHS2 mutations in late-onset focal segmental glomerulosclerosis: R229Q is a common disease-associated allele. J Clin Invest 2002;110:1659-1666.
43 Koziell A, Grech V, Hussain S, Lee G, Lenkkeri U, Tryggvason K, Scambler P: Genotype/ phenotype correlations of NPHS1 and NPHS2 mutations in nephrotic syndrome advocate a functional inter-relationship in glomerular filtration. Hum Mol Genet 2002;11:379-388.

44 Bariety J, Nochy D, Mandet C, Jacquot C, Glotz D, Meyrier A: Podocytes undergo phenotypic changes and express macrophagic-associated markers in idiopathic collapsing glomerulopathy. Kidney Int 1998;53:918-925.

45 Snyers L, Umlauf E, Prohaska R: Oligomeric nature of the integral membrane protein stomatin. J Biol Chem 1998;273:17221-17226.

46 Schnabel E, Anderson JM, Farquhar MG: The tight junction protein ZO-1 is concentrated along slit diaphragms of the glomerular epithelium. J Cell Biol 1990;111:1255-1263.

47 Kurihara H, Anderson JM, Farquhar MG: Increased Tyr phosphorylation of ZO-1 during modification of tight junctions between glomerular foot processes. Am J Physiol 1995;268: F514-F524

48 Macconi D, Ghilardi M, Bonassi ME, Mohamed EI, Abbate M, Colombi F, Remuzzi G, Remuzzi A: Effect of angiotensin-converting enzyme inhibition on glomerular basement membrane permeability and distribution of zonula occludens-1 in MWF rats. J Am Soc Nephrol 2000;11:477-489.

49 Kreidberg JA: Functions of alpha3beta1 integrin. Curr Opin Cell Biol 200012:548-553.

50 Adler S: Heparin alters epidermal growth factor metabolism in cultured rat glomerular epithelial cells. Am J Pathol 1991;139:169-175.

51 Adler S, Chen X: Anti-Fx1A antibody recognizes a beta 1-integrin on glomerular epithelial cells and inhibits adhesion and growth. Am J Physiol 1992;262:F770-F776.

52 Adler S, Sharma R, Savin VJ, Abbi R, Eng B: Alteration of glomerular permeability to macromolecules induced by cross-linking of beta 1 integrin receptors. Am J Pathol 1996;149:987996.

53 Kambham N, Tanji N, Seigle RL, Markowitz GS, Pulkkinen L, Uitto J, D'Agati VD: Congenital focal segmental glomerulosclerosis associated with beta4 integrin mutation and epidermolysis bullosa. Am J Kidney Dis 2000;36: 190-196.

54 Kriz W, Gretz N, Lemley KV: Progression of glomerular diseases: Is the podocyte the culprit? Kidney Int 1998;54:687-697.

55 Kretzler M, Koeppen-Hagemann I, Kriz W: Podocyte damage is a critical step in the development of glomerulosclerosis in the uninephrectomised-desoxycorticosterone hypertensive rat. Virchows Arch 1994;425:181-193.

56 Nagata M, Kriz W: Glomerular damage after uninephrectomy in young rats. II. Mechanical stress of podocytes as a pathway to sclerosis. Kidney Int 1992;42:148-160.

57 Drenckhahn D, Franke RP: Ultrastructural organization of contractile and cytoskeletal proteins in glomerular podocytes of chicken, rat, and man. Lab Invest 1988;59:673-682. 
58 Andrews PM: Investigations of cytoplasmic contractile and cytoskeletal elements in the kidney glomerulus. Kidney Int 1981;20:549562.

59 Mundel P, Heid HW, Mundel TM, Krüger M, Reiser J, Kriz W: Synaptopodin: An actin-associated protein in telencephalic dendrites and renal podocytes. J Cell Biol 1997;139:193204.

60 Mundel P, Gilbert P, Kriz W: Podocytes in glomerulus of rat kidney express a characteristic 44 KD protein. J Histochem Cytochem 1991; 39:1047-1056.

61 Kaplan J, Pollak MR: Familial focal segmental glomerulosclerosis. Curr Opin Nephrol Hypertens 2001;10:183-187.

62 Barisoni L, Kriz W, Mundel P, D'Agati V: The dysregulated podocyte phenotype: A novel concept in the pathogenesis of collapsing idiopathic focal segmental glomerulosclerosis and HIVassociated nephropathy. J Am Soc Nephrol 1999;10:51-61.

63 Kemeny E, Durmüller U, Nickeleit V, Gudat F, Mihatsch MJ: Distribution of podocyte protein $(44 \mathrm{KD})$ in different types of glomerular diseases. Virchows Arch 1997;431:425-430.

64 Srivastava T, Garola RE, Whiting JM, Alon US: Synaptopodin expression in idiopathic nephrotic syndrome of childhood. Kidney Int 2001;59:118-125.

65 Lehtonen S, Zhao F, Lehtonen E: CD2-associated protein directly interacts with the actin cytoskeleton. Am J Physiol Renal Physiol 2002;283:F734-F743.

66 Yuan H, Takeuchi E, Salant DJ: Podocyte slitdiaphragm protein nephrin is linked to the actin cytoskeleton. Am J Physiol Renal Physiol 2002;282:F585-F591.

67 Yuan H, Takeuchi E, Taylor GA, McLaughlin M, Brown D, Salant DJ: Nephrin dissociates from actin, and its expression is reduced in early experimental membranous nephropathy. J Am Soc Nephrol 2002;13:946-956.

68 Kerjaschki D, Sharkey DJ, Farquhar MG: Identification and characterization of podocalyxin - the major sialoglycoprotein of the renal glomerular epithelial cell. J Cell Biol 1984;98: 1591-1596.

69 Schnabel E, Dekan G, Miettinen A, Farquhar MG: Biogenesis of podocalyxin - the major glomerular sialoglycoprotein - in the newborn rat kidney. Eur J Cell Biol 1989;48:313-326.

70 Takeda T, Go WY, Orlando RA, Farquhar MG: Expression of podocalyxin inhibits cellcell adhesion and modifies junctional properties in Madin-Darby canine kidney cells. Mol Biol Cell 2000;11:3219-3232.

71 Thomas PE, Wharram BL, Goyal M, Wiggins JE, Holzman LB, Wiggins RC: GLEPP1, a renal glomerular epithelial cell (podocyte) membrane protein-tyrosine phosphatase: Identification, molecular cloning, and characterization in rabbit. J Biol Chem 1994;269:1995319962.
72 Wharram BL, Goyal M, Gillespie PJ, Wiggins JE, Kershaw DB, Holzman LB, Dysko RC, Saunders TL, Samuelson LC, Wiggins RC: Altered podocyte structure in GLEPP1 (Ptpro)deficient mice associated with hypertension and low glomerular filtration rate. J Clin Invest 2000;106:1281-1290.

73 Kreidberg JA, Sariola H, Loring JM, Maeda M, Pelletier J, Housman D, Jaenisch R: WT-1 is required for early kidney development. Cell 1993;74:679-691.

74 Dressler GR, Wilkinson JE, Rothenpieler UW, Patterson LT, Williams-Simons L, Westphal $\mathrm{H}$ : Deregulation of Pax-2 expression in transgenic mice generates severe kidney abnormalities. Nature 1993;362:65-67.

75 Yang Y, Jeanpierre C, Dressler GR, Lacoste M, Niaudet P, Gubler MC: WT1 and PAX-2 podocyte expression in Denys-Drash syndrome and isolated diffuse mesangial sclerosis. Am J Pathol 1999;154:181-192.

76 Barisoni L: Podocyte cell cycle regulation and proliferation in collapsing glomerulopathies. Kidney Int 2000;58:81-87.

77 Shankland SJ, Eitner F, Hudkins KL, Goodpaster T, D'Agati V, Alpers CE: Differential expression of cyclin-dependent kinase inhibitors in human glomerular disease: Role in podocyte proliferation and maturation. Kidney Int 2000;58:674-683.

78 Quaggin SE: Transcriptional regulation of podocyte specification and differentiation. Microsc Res Tech 2002; 57:208-211.

79 Quaggin SE, Schwartz L, Cui S, Igarashi P, Deimling J, Post M, Rossant J: The basichelix-loop-helix protein Pod 1 is critically important for kidney and lung organogenesis. Development 1999; 126:5771-5783.

80 Rohr C, Prestel J, Heidet L, Hosser H, Kriz W, Johnson RL, Antignac C, Witzgall R: The LIMhomeodomain transcription factor $\mathrm{Lmxlb}$ plays a crucial role in podocytes. $\mathrm{J}$ Clin Invest 2002;109:1073-1082.

81 Miner JH, Morello R, Andrews KL, Li C, Antignac C, Shaw AS, Lee B: Transcriptional induction of slit diaphragm genes by $\mathrm{Lmxlb}$ is required in podocyte differentiation. J Clin Invest 2002;109:1065-1072.

82 Sadl V, Jin F, Yu J, Cui S, Holmyard D, Quaggin S, Barsh G, Cordes S: The mouse Kreisler (Krml1/MafB) segmentation gene is required for differentiation of glomerular visceral epithelial cells. Dev Biol 2002;249:16-29.

83 Mundel P, Shankland SJ: Podocyte biology and response to Injury. J Am Soc Nephrol 2002;13: 3005-3015.

84 Kriz W, Kobayashi N, Elger M: New aspects of podocyte structure, function, and pathology. Clin Exp Nephrol 1998;2:85-99.

85 Mundel P, Shankland SJ: Glomerular podocytes and adhesive interaction with glomerular basement membrane. Exp Nephrol 1999;7: 160-166.

86 Meyer TW, Bennett PH, Nelson RG: Podocyte number predicts long-term urinary albumin excretion in Pima Indians with type II diabetes and microalbuminuria. Diabetologia 1999;42: 1341-1344.
87 Pagtalunan ME, Miller PL, Jumping-Eagle S, Nelson RG, Myers BD, Rennke HG, Coplon NS, Sun L, Meyer TW: Podocyte loss and progressive glomerular injury in type II diabetes. J Clin Invest 1997;99:342-348.

88 Steffes MW, Schmidt D, McCrery R, Basgen JM, Group ID: Glomerular cell number in normal subjects and in type 1 diabetic patients. Kidney Int 2001;59:2104-2113.

89 Kim YH, Goyal M, Kurnit D, Wharram B, Wiggins J, Holzman L, Kershaw D, Wiggins R: Podocyte depletion and glomerulosclerosis have a direct relationship in the PAN-treated rat. Kidney Int 2001;60:957-968.

90 Schiffer M, Bitzer M, Roberts IS, Kopp JB, ten Dijke P, Mundel P, Böttinger EP: Apoptosis in podocytes induced by TGF-beta and Smad7. J Clin Invest 2001;108:807-816.

91 Böttinger EP, Bitzer M: TGF-beta signaling in renal disease. J Am Soc Nephrol 2002;13: 2600-2610.

92 Border WA, Ruoslahti E: Transforming growth factor-beta 1 induces extracellular matrix formation in glomerulonephritis. Cell Differ Dev 1990;32:425-431.

93 Shankland SJ, Hugo C, Coats SR, Nangaku M, Pichler RH, Gordon KL, Pippin J, Roberts JM, Couser WG, Johnson RJ: Changes in cell-cycle protein expression during experimental mesangial proliferative glomerulonephritis. Kidney Int 1996;50:1230-1239.

94 Shankland SJ: Cell-cycle control and renal disease. Kidney Int 1997;52:294-308.

95 Schiffer M, von Gersdorff G, Bitzer M, Susztak K, Böttinger EP: Smad proteins and transforming growth factor-beta signaling. Kidney Int Suppl 2000;77:45-52.

96 Schnaper HW, Hayashida T, Poncelet AC: It's a Smad world: Regulation of TGF-beta signaling in the kidney. J Am Soc Nephrol 2002;13:1126-1128.

97 Border WA, Noble NA: Transforming growth factor beta in tissue fibrosis. N Engl J Med 1994;331:1286-1292.

98 Kerjaschki D: Caught flat-footed: Podocyte damage and the molecular bases of focal glomerulosclerosis. J Clin Invest 2001;108: 1583-1587.

99 Schumacher V, Schärer K, Wuhl E, Altrogge H, Bonzel KE, Guschmann M, Neuhaus TJ, Pollastro RM, Kuwertz-Broking E, Bulla M, Tondera AM, Mundel P, Helmchen U, Waldherr R, Weirich A, Royer-Pokora B: Spectrum of early onset nephrotic syndrome associated with WT1 missense mutations. Kidney Int 1998;53:1594-1600.

100 Barisoni L, Bruggeman LA, Mundel P, D'Agati VD, Klotman PE: HIV-1 induces renal epithelial dedifferentiation in a transgenic model of HIV-associated nephropathy. Kidney Int 2000;58:173-181. 